\title{
Exploring Entrepreneurial Finance and Gender in an Emergent Entrepreneurial Ecosystem: the case of the Punjab, Northern India
}

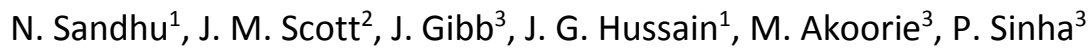 \\ ${ }^{1}$ Birmingham City University, Birmingham, United Kingdom \\ ${ }^{2}$ Teesside University, Middlesbrough, United Kingdom \\ ${ }^{3}$ The University of Waikato, Hamilton, New Zealand
}

\section{Introduction}

Women's access to entrepreneurial finance in emerging economies, which have nascent or emergent entrepreneurial ecosystems, is an under-researched area (Hussain and Scott, 2015). This exploratory chapter offers contextualized empirical evidence and theory (Welter, 2011; Zahra, 2007; Zahra et al., 2014) of how entrepreneurial finance supports women-led firms in an emergent entrepreneurial ecosystem within the state of Punjab, in northern India. This emergent entrepreneurial ecosystem illustrates women's embeddedness within a cultural milieu, social structure and their family role expectations. The importance of this context, which this chapter seeks to explore, is notably absent from the extant literature on agglomeration in Western societies that has dominated thinking to date. Manolova et al.'s (2016) introductory chapter provides a theorization of entrepreneurial ecosystems to include key components of markets, human capital, finance, education/training and policy. Stam's (2015, p. 5) definition of an entrepreneurial ecosystem as a "set of interdependent actors and factors coordinated in such a way that they enable productive entrepreneurship," is particularly relevant and insightful. In this chapter we offer a novel contextualized example within urban and rural settings in the Punjab, northern India, where these key components are present (but at an emergent stage) in this bottom-up entrepreneurial ecosystem. 
By emphasizing the social, cultural, and informal aspects, we posit that the Punjab context is an emergent entrepreneurial ecosystem in which informal institutions (social structure, culture, entrepreneurs, households, and lenders) and more formal institutions (such as formalized bank lending and educational establishments) are interwoven and interdependent. While the development of a complete entrepreneurial ecosystem is beyond the scope of this chapter, we do develop a framework that we use to examine the roles of entrepreneurial finance and gender in the growth of entrepreneurial firms from our data.

Entrepreneurs are central to the concept of entrepreneurial ecosystems (Manolova et al. 2016, citing Stam, 2015), whereas industrial districts ${ }^{1}$ and industrial clusters ${ }^{2}$ are firmcentric concepts in the Western literature which attempted to explain regional economic development. Although Marshall never used the term 'clustering' in his writing, he was describing the agglomeration of industries with 'same type' workers in $18^{\text {th }}$ and $19^{\text {th }}$ Century industrial England. However, as well as being too firm-centric, these two divergent views are clearly Western-centric and in the unique context of emerging economies are wholly inappropriate to describe these emergent entrepreneurial ecosystems. While the impact of such cultural phenomena upon women-led firms has been explored in a variety of diverse developmental and spatial contexts (e.g. sub-Saharan Africa and elsewhere), their impact cannot be generalized to dissimilar contexts, such as India, where entrepreneurial ecosystems are different across regions and between urban and rural parts in the same region.

\footnotetext{
${ }^{1}$ Industrial districts have 'same type' workers, who are mobile across different industries, whereas the 'neoMarshallians' of the present age have identified the presence of industrial districts in locations such as Northern Italy (Emilia-Romagna), where 'same type' workers provide the labour pool for such diverse industries as food processing, yacht building and precision manufacturing (Akoorie, 2011).

${ }^{2}$ Porterian type clusters, taking an instrumental approach, explain the growth of 'same type' industries which have related and supporting industries, embedded in a 'hard' physical infrastructure and a complementary 'soft' infrastructure such as institutions for training and networks for disseminating information (Porter, 1990).
} 
The remainder of the chapter is organised in the following way. In Section 2 we discuss prior theory and evidence on women entrepreneurs in emerging economies, developing from that a model of an emergent entrepreneurial ecosystem to show the influence of entrepreneurial finance and gender. Section 3 discusses the research methodology and the methods used to collect the data, while Section 4 outlines our results. In Section 5 we conclude the paper by developing a set of propositions to inform further research.

\section{Prior Theory and Evidence on Women's Entrepreneurship in Emerging Economies}

Levels of entrepreneurship in India have increased in recent decades (Singer et al., 2015) as evidenced by output, attitude and framework indicators (Ács et al., 2014) such as the National Systems of Entrepreneurship. Yet, according to these authors, these indicators fail to capture levels of entrepreneurship accurately, as they aggregate un-contextualized measures, and are a-processual and a-behavioural. Significant research and knowledge gaps exist in terms of women's contribution to economic development, especially in emerging economies (Brush and Cooper, 2012, p. 4). These authors note in particular that 'the vast majority of research about women entrepreneurs is still very Western centric' in developing regions, including the Indian subcontinent, [they] lack empirical evidence and contextualized theorization (p. 4). In this chapter, we respond to their call for studies using different approaches. As Brush and Cooper (2012, p. 4) state, 'more and more women are involved in growing their businesses ... and the need to focus on the many challenges ... as they seek to maintain the entrepreneurial effort of their ventures.' 
A number of relatively recent studies examining entrepreneurship in India focus on, inter alia, social and human capital (Bhagavatula et al., 2010; Nafziger and Terrell, 1996), innovation (Birtchnell, 2011), firm growth (Coad and Tamvada, 2012), informal firms (Gurtoo, 2009), clusters (Henn, 2013; Keshabananda, 1998), economic development (Koster and Kumar Rai, 2008), finance (Latha and Murthy, 2009; Shetty, 2009), gender (Parida and Sinha, 2010; Rai and Srivastava, 2011), entrepreneurial orientation (Ramachandran and Ramnarayan, 1993) and small-scale industries (Singh, 2010). However, there is a dearth of evidence or rigorous theory about women's ability to access entrepreneurial finance in gendered rural and urban ecosystemic contexts, or on entrepreneurial ecosystems in India more generally. Although large-scale cross-country comparative analyses ${ }^{3}$ on entrepreneurship as a measure or proxy of start-up within both developed and emerging economies (e.g. Ács et al., 2008; Ács and Amorós, 2008; Desai, 2009; Kelley et al., 2013; Amorós and Bosma, 2014) have been conducted, nonetheless it remains unclear whether these datasets provide an accurate and plausible picture of entrepreneurship and small business in emerging economy contexts. We query whether inter-country comparisons or temporal changes in entrepreneurship and business ownership rates are valid and reliable. The purpose of this chapter is to develop a small-scale study of entrepreneurship and small business in the Punjab area of India to provide in-depth insights into the role of women entrepreneurs in this region.

With respect to country-level and individual diversity of entrepreneurship, Roper (2013) argues the need for studies to be 'strongly contextual' (in particular, linking structure (e.g. institutions) and agency (actions or behaviour of individuals) and he highlights the “inadequacy - or perhaps more accurately, the irrelevance - of taught 'models' of

\footnotetext{
${ }^{3}$ Using Global Entrepreneurship Monitor (GEM), Organization for Economic Cooperation and Development (OECD) and World Bank Global Entrepreneurship (WBGES) data.
} 
entrepreneurial behaviour for many countries" (Roper, 2013, p. 2). Kobeissi (2010, p. 1) adds that there is a "need for more global and diversified analysis of female entrepreneurial activities' because of scant prior evidence and theory in emerging economies. Consequently, we next review extant evidence on entrepreneurial finance and gender in emerging economies and position those within our proposed framework of emergent entrepreneurial ecosystems (Figure x.1). To appreciate the significance of the entrepreneurial ecosystem within the Indian Punjab, it is important to understand the context in which this study was carried out. The Punjab is an agriculture-based economy. The state has a 'balanced amalgamation of heat in summer, rain in monsoon and cold in winter. Punjab experiences both summer and winter at its extreme' (Government of India, 2016). The economic growth and transformation of the Punjab economy through the Green revolution has given it the status of the "grain bowl of India". The achievements of the Punjab have been widely recognised and reported by such institutions as the World Bank $(2004 ; 2009)$.

The Punjab has an area of 50,362 square kilometres with a population of 29,673,462, of which 66 percent are based in the rural areas (Population of India, 2016). There are 13,069,417 females in Punjab (the sex ratio is 893 females per 1000 males). Despite the low male-female ratio due to preferences for boys (gender discrimination), the Punjab still stands fourth in terms of the number of women entrepreneurs amongst the other Indian States. There are 4,791 registered enterprises and 1,618 (33.77 per cent) are owned by women (MSME, 2016). The literature suggests that women's work participation in India is 31.6 per cent, whereas in the USA it is 45 per cent, UK 43 per cent, Canada 42 percent and Sri Lanka 35 percent (International Finance Corporation, IFC, 2015). Socio-cultural barriers, low education levels and training, lack of funds, confidence, and adequate collateral and financial awareness are some of the various explanatory factors behind the low economic participation rates of women in India (Sandhu et al., 2012). 


\subsection{Entrepreneurial finance and gender in emergent entrepreneurial ecosystems}

\subsubsection{Financial capital and gender}

Financial capital and human capital are critical components of new venture creation, growth and survival in developmentally diverse economies (Vivarelli, 2013). There is limited evidence of the benefits of microfinance (Morduch, 1999), as confirmed by studies in Algeria (Smahi et al., 2012) and Guatemala, but Wydick (2002) provides contextual evidence of microfinance in practice, finding that women performed better in terms of retention, job creation and venture survival. Still, there are 'important benefits and limitations of microfinance as a development tool ... credit access may be a binding constraint to growing an enterprise' (ibid, p. 507). Campbell and Rogers (2012, p. 4) note that 'women are less risky borrowers' for microfinance (citing Parida and Sinha, 2010) and that such microfinance institutions (MFIs) 'with a larger percentage of women borrowers fare better'. Campbell and Rogers (2012, p .9) suggest that MFIs 'perhaps preferentially lend ... to women.'

Woller and Woodworth (2001, p. 1) define microcredit as 'programs that extend small loans to poor people for self-employment projects that generate income'. A narrative content analysis revealed that investors feel a warm glow (good about themselves) by investing in the business of poor entrepreneurs; such loans may be approved more speedily if business or managerial language is used by the entrepreneurs (Allison et al., 2013). So there can be positive outcomes of microfinance both on the demand side (borrower) and supply side (the lender/investor). Furthermore, Kent and Dacin (2013) observe a displacement effect upon MFIs. 'Commercial banking logic' may overpower the original raison d'être of MFIs which is to reduce poverty. Entrepreneurship and self-employment are, however, themselves highly commercially driven (profit oriented), while the aim of development-driven MFIs is to help poor entrepreneurs by providing financial capital. 
There is a lack of strong evidence that MFIs and microfinance have been particularly effective at providing genuine economic opportunities for the impoverished in emerging economies (e.g. Morduch, 1999), or that MFIs (paralleling the debate on social enterprises in developing economies) are operating in a sustainable and commercial manner. While MFIs do provide credit for entrepreneurial start up and self-employment entry, these are such small-scale loans that the opportunities for any sort of major venture growth are highly limited (see also evidence of commercially successful MFIs in Nigeria (Makarfi and Olukosi, 2011)). Many extant studies have analysed microfinance from an institutional (MFI) perspective, and have examined credit access from the point of view of the entrepreneur, for example, in Jamaica (Williams and K'nIfe, 2008) and Bangladesh (Habib and Shah, 2010). Notably, Williams and K'nIfe's (2008) study found that Jamaican women had lower levels of human capital (education/work experience), and obtained lower levels of bank lending.

Additionally, studies of women in emerging economies (Prasad, 2009; Muravyev et al., 2009) found that there were higher levels of 'discouraged' borrowing.

Mutual Guarantee Associations (MGAs) in Africa are SME-bank intermediaries that enable microenterprise founders to obtain financial capital required to invest in their business (De Gobbi, 2003). However, MGAs perform poorly relative to their longer established counterparts in the West. Micro-enterprises in Sri Lanka received grants from MFIs but men who had 'more ability' had the highest returns (de Mel et al., 2008, 2014), with evidence of bootstrap finance for men in another Sri Lankan study (Peiris et al., 2015). Women are generally considered to be 'better bets' for micro financing; however, formal lending institutions banks) in emerging economies have credit constraints. Equity-based funders tend to prefer state-owned enterprises in China and Vietnam (Perri and Chu, 2012), while in Zimbabwe finance provision to entrepreneurs has not offset their propensity to fail (Nziramasanga et al., 2009). Indeed, finance for all start-ups in a survey of 196 firms in 
Nellore, India was sourced largely from family (41.8 percent) but also banks, (35.7 percent) (Latha and Murthy, 2009). Family support is a major influencer. Shetty (2009) advocates that MFIs should provide support and advice as well as finance. This would strengthen firm performance, encourage sustainability and lead to better repayment rates, a view supported by Irwin et al. (2014). Olarenwayi and Olabisi (2012) interviewed thirty (Nigerian) Yoruba women artisans ['textile traders'] who would not borrow money from banks or from MFIs either because of the high cost of credit or the inadequate size of the loan offered. They used a variety of sources including the reinvestment of profits and supplier credit. Other major sources of credit were informal sources such as families (i.e. husbands) or other property related sources, (selling houses or rental income). Even graduates in Pakistan with ideas, a form of human capital, face capital constraints which prevent them starting up businesses (Iftekar et al., 2013). Hartwell (2014) suggests that capital controls, a government macroeconomic policy, discourages entrepreneurship. This finding suggests that such institutional factors may impact entrepreneurial finance. However, a consideration of institutional factors is not within the scope of our study. Commercial banking is not viable or not even accessible to impoverished people - particularly women - in emerging economies. The issues in poor rural and urban areas with informal enterprises are creditworthiness, high transaction costs and information asymmetry, where MFIs have developed as a replacement for commercial banking (Khavul, 2010). Although 'repayment rates and sustainability' are problematic for MFIs, group lending and social (capital) connections ensure repayment (Wydick, 1999; Khavul, 2010). Khavul (2010, pp. 65-66) highlights the mixed evidence on 'outcomes' for MFI borrowers and the 'empowerment of women'. Attempts to overcome the traditional patriarchal control of women within this context have been outmanoeuvred by some men who still control the money (Rahman, 1999). Chile's entrepreneurs are also undercapitalised which suggests the apparent persistence of a 'finance gap' (Romani et al., 2009). 
Ács et al. (2011, p. 393) highlight how entrepreneurship and development economics have 'developed [sic] in isolation ... from each other'. There is a notable convergence between institutions who emphasize 'open discrimination, most implicitly by lenders but perhaps also within other networks which provide credit, often of a more informal type' (ibid, p. 395). In this environment women may have lower start up rates than men; they also shoulder the burden of childcare, domestic work which may affect their own 'preferences'. Indeed, gender differences have been explored in a variety of diverse spatial contexts such as sub-Saharan Africa (Amine and Staub, 2009; Aterido and Hallward-Driemeir, 2011; Bardasi et al., 2011), and Mexico (Bruhn and Love, 2011). Sub-Saharan African women face constraints in dealing with institutions which are characterized by their particular 'regulatory, normative and cognitive environments and involve complex issues of social legitimacy' (Amine and Staub, 2009, p. 207). These constraints include the hegemony of certain ethnic groups, resulting in credit constraints and limited access to microfinance (ibid, p. 197).

\subsubsection{Gender, financial capital, human capital, and social capital}

Whilst the 'gender discrimination' hypothesis is not supported by Bardasi et al.'s (2011) quantitative empirical study, nonetheless in Eastern Europe and Central Asia (ECA) women were 'less likely to apply for credit than men', but 'as likely' in Latin America (LA) and SubSaharan Africa (SSA). Indeed, 'we find some evidence of credit constraints on the demandside (in ECA), but not on the supply-side' (ibid, p, 436). Bardasi et al (2011, p. 417) also found that women yielded equal 'returns' per dollar but had smaller loan sizes and higher credit costs, with women-led firms in ECA, LA and SSA being smaller, more sectorally concentrated but showing relatively fewer differences in other performance measures such as 'efficiency and growth'. 
Cetindamar et al. (2012) found that 'human, family [social] and financial capital' all contributed to start ups in Turkey. Human capital was more influential for women, while access to financial capital was the same for both women and men. In countries with high levels of corruption and regulation (institutional factors), the higher entrepreneurship rates (Chowdhury and Audretsch, 2014) appear to mitigate the impact of these institutional factors. A study of ten highly educated women entrepreneurs in Bahrain/Oman found that they utilized little financial capital as a consequence of debt aversion in their culture and either used their own resources- or social capital. Both these means of funding constrained their venture growth considerably (Dechant and Al Lamky, 2005). Della-Giusta and Phillips (2006) found that growth constraints such as education (human capital) and finance (financial capital) impeded the growth of women entrepreneurs in the Gambia, but these entrepreneurs did overcome these constraints by using family resources e.g. information. Yet, 'some women entrepreneurs are pressurized by husbands to use revenue for non-business purposes', leaving the firm constrained further financially (ibid, p. 1061). Elam and Terjesen (2010) suggest that institutions, both soft and hard, relating to occupation, wages, leadership and childcare also affect start-up rates by women.

Further evidence of financial constraints impeding women entrepreneurs can be found in Afghanistan (Holmén et al., 2011), and Indonesia (Loh and Dahesihsari, 2013; Singh et al. 2011; Tambunan, 2007, 2008). For example, such women were resilient, knew how to cope with negative business experiences, and though not highly educated they had 'talent' and 'good business sense and management skills'. These skills were fostered through mentoring, an important aspect of social capital (Loh and Dahesihari, 2013, p. 117). Counterintuitively, having huge financial capital was not crucial for the start-up as women initiated 'home based or service oriented' businesses which had low start-up costs e.g. (ibid, p, 117). 
Social capital was, therefore, more important than human capital and financial capital. Singh et al. (2001, p. 181) found that 200 women entrepreneurs in Java were 'concentrated in more traditional and less dynamic markets - low income informal sectors, where prospects of growth were limited'. Other constraints for women entrepreneurs (Tambunan, 2008) included regulation, finance, human resources and technology. Traditional culture and human capital were also found to be major constraints (Tambunan, 2007). On the positive side, evidence of empowerment was found in a case study of the herbal medicinal plant in a 'women-led Community Enterprise', the Gram Mooligai Company Limited (GMCL), in India (Torri and Martinez, 2014). Uniquely, these women are from the scheduled tribes (the so-called 'untouchables'), exemplifying 'a gender collective enterprise which focuses primarily on bringing women into the economic mainstream and social enhancement by broadening their options and thereby increasing their likelihood of success and reducing their dependence on outside sources of support' (ibid, p. 45).

The above literature provides an overall assessment of emerging entrepreneurial ecosystems. Although not specifically conceptualized as such, it explicitly recognizes the role of women in entrepreneurship and the constraints they face in growing their firms. Extant literature and theory is highly Western centric, we might even suggest neo-colonialist, in its outlook and perspective but it is clear that the more insightful studies are those which are contextualized (Welter, 2011; Roper, 2013). These studies show structure-agency linkages (Roper, 2013). Entrepreneurial ecosystems, as an emergent form, illustrates the interconnections and interrelationships between structure and agency. 
The extant evidence on entrepreneurial finance and gender in emerging economies does, however, highlight the importance of human capital and social capital. However, the way in which these relationships can be converted into financial capital is less clear. There is also a mixed picture connecting MFIs and self-employment. A strongly positioned theory such as that of emergent entrepreneurial ecosystems could clarify these issues. So, generally speaking there is a considerable gap in our understanding of the entrepreneurial ecosystems in which women entrepreneurs in India are based and the ways in which they access entrepreneurial finance. So, just what are the factors within society and the underpinning culture in India which can influence (help or hinder) the ability of women's efforts to secure finance for growth? Below we, therefore, develop an emergent entrepreneurial ecosystem model of sources of entrepreneurial finance and gender to account for such contextual differences.

\section{$2.2 \mathrm{~A}$ model of an emergent entrepreneurial ecosystem and the role of finance and gender}

This model synthesizes our empirical material with prior studies such as that of Nichter and Goldmark (2009) who reviewed the literature on financial, human and social capital for women entrepreneurs. In our model, women entrepreneurs are the central actors in the following three contexts: the role of women; entrepreneurial financial sources and societal progress. For each context we identify a dominant coordinating mechanism: (non) traditional; (in) formal; and cultural-societal factors. More importantly, we discuss in our findings how a set of factors present within each of these coordinating mechanisms influences the nature and direction of change and the subsequent emergence of this entrepreneurial ecosystem. These influences, which are shown by the bi-directional arrows in our model include: class structure; family support; gender issues and education. 


\section{Research Sample and Methodology}

We used a blended approach to data collection, administering 300 questionnaires to selected women entrepreneurs located in five districts (Gurdaspur, Amritsar, Jalandhar, Nawanshahr and Patiala $)^{4}$ of the Punjab, India. Of the 300 questionnaires delivered, 185 valid responses were collected: giving a response rate of 61 percent. One of the authors went to the Punjab to administer this survey and to collect the interview data for this study. This was a purposive sample as the authors believed that respondents selected were the most appropriate people to be interviewed. We designed a semi-structured questionnaire specifically for this study and sought to collect data relating to demographic characteristics and background, as well as loan usage, perceptions, motivations and challenges faced by women entrepreneurs (WEs). One author carried out interviews lasting 30-50 minutes, with women entrepreneurs who were willing to cooperate. 150 out of 185 showed their interest but - due to time, logistical and financial constraints - only 50 women were interviewed. The qualitative part of the study included interviews that helped us to obtain deeper insights into various 'soft' issues faced by women entrepreneurs. At the initial stage of the interview section of the study the researcher in the Punjab conducted a pilot survey with 20 respondents to ensure the reliability of data gathered and the overall process, and confirmed the suitability of the approach prior to proceeding with interviews. The author responsible for collecting the interview data used a snowball technique that relied on the researcher's networks, local knowledge and relevant language skills. Interviews were digitally recorded, transcribed verbatim, and then analysed. On completion of the analysis, a summary of research findings was shared with the respondents of both research samples, the survey respondents and the interviewees.

\footnotetext{
${ }^{4} 20$ per cent rural (villages), 55 per cent semi-urban (towns), 25 per cent urban (cities Gurdaspur, Amritsar, Jalandhar and Patiala).
} 


\section{Results}

The challenges faced by women entrepreneurs are attributable to various factors such as their personal or individual characteristics (lack of education, confidence, decision making), gender and family factors (gender discrimination, sexual harassment, lack of support from the family or spouse, lack of recognition from the community) and market-based challenges (economic conditions, lack of access to networks and institutional factors). We provide a guide and structure to our findings with the ecosystem model (Figure x.1) introduced earlier. First, we examine women entrepreneurs' role including: family support and access to education. Second, we discuss their sources of finance. Third, we examine societal progress in terms of women's involvement in business. Within each section, we highlight the coordinating mechanism and its influencing factors.

\subsection{Non Traditional Role of woman}

\subsubsection{Limited access to education and vocational training}

90 percent (45 out of 50) of the women entrepreneurs in the interviews were concerned that they have less access to education than their male counterparts. Often even if training is available, women find either that the timing conflicts with family responsibilities, or that the content and method of delivery is inappropriate. Besides, most technical training that is offered to girls at the post-school levels (in women's polytechnics, for instance) is limited to traditional careers, such as secretarial practice or dress design. Thus, the exclusivity of training acts as a limiting factor.

\section{<INSERT TABLE X.1 ABOUT HERE>}

The respondents emphasized the need for female education, diverse vocational training and support (financial and infrastructural) for women in general and the Punjab specifically. The lack of proper hostel facilities with adequate arrangements was a major 
cause of poor occupancy rates. Parents were averse to sending their daughters to such institutes. As one of the respondents mentioned:

"I am reluctant to send my daughter away from home as I am worried about her security. Therefore, I prefer to keep her at home. Once she is married, then she can do whatever she wants with the consent of her husband and in-laws." (WE5)

Fifty percent of respondents reported that they had increasing empowerment and autonomy within the household, while in contrast 45 percent reported that they still have less autonomy. Respondents perceived gains in economic independence after they started their own businesses.

\subsubsection{Lack of support and recognition from family}

Fifty percent of respondents reported that borrowing money to establish a new firm affected their life positively, using the loan productively, to start a boutique (40\%) or a small shop $(10 \%)$. Others used funds to repair their house $(5 \%)$, to educate children $(15 \%)$, or for the marriage of their siblings or children (20\%). However, ten percent reported that they were abused or beaten, and that their substance-addicted husbands stole the money. Since society puts an added responsibility onto women in addition to their roles as mothers and wives, the time spent and the emotional burden created by these dual role responsibilities impacted directly on women in ways that do not apply to the majority of men. Although women contributed towards the family business, their contribution was often not recognized as it was mostly in the form of unpaid effort and skills. Thirty percent helped in the family business but the value of this effort was underestimated by families who take it for granted. It also affected their progress in academic studies. There are some enterprises, although defined as being run by women (in which women hold the controlling share), which were only nominally women entrepreneurs. Men, who controlled the operations and made the decisions in fact, ran them. 


\subsection{Socio-cultural factors influencing sources of finance used by women entrepreneurs}

Thirty percent of women obtained loans from the bank while others used informal finance.

Table x.2 shows the relationship between the age of the business and access to bank finance. $75 \%$ of respondents reported that they initially approached the bank for financing but their loan requests were rejected mainly because they lacked collateral. However, the lack of access to bank finance limits firms' access to credit. Access to credit is strongly tied to fluctuations in retained earnings, which are highly correlated with macroeconomic fluctuations. Furthermore, as firms face asymmetric information problems in the credit markets, they are likely to need to pay a premium to obtain credit or outside equity.

The reluctance of lending institutions to lend to SMEs can be explained as follows. The small amount of loans normally applied for creates high per unit loan costs for banks, making it uneconomical for them to lend to firms. They have poor track records and weak financial accounting systems. The banks' demand for adequate collateral is not met. This explanation can be applied to women entrepreneurs in SMEs as well.

\section{<INSERT TABLE X.2 ABOUT HERE>}

Interestingly, in our sample, 13 percent of women entrepreneurs obtained loans from the bank as seven percent were able to provide collateral, while the remaining six percent said that status and family relationships played an important role in gaining access to bank finance. Two women entrepreneurs reported that:

"I did not have collateral but the loan officer was my brother's/husband's friend so getting a loan from the bank was not a problem", while the remaining four said "in every area everyone knows my family so the daughter or daughter-in-law or wife or sister of so and so helped me to access formal finance without any problems." (WE15 and WE37) 
These findings suggest that personal relationships, family background/status and the role of kinship (family members' recommendations) play important roles for accessing finance, not only from formal but also from informal sources.

While the remaining 70 percent of women entrepreneurs had to rely on informal sources of finance, 30 percent relied entirely on personal savings or family and friends, while the remaining women entrepreneurs could not get much help from the family; hence they had to explore other sources of informal finance such as arthiyas (retail merchants), ghumihar (potters), kirana store owners (village/town grocer), shahukars (village/town goldsmith) and zamindars (landlords) (see also Sandhu et al., 2015).

\section{<INSERT TABLE X.3 ABOUT HERE>}

Indeed, rural women mainly approached arthiyas, ghumihars, landlords or shahukars for funds, while the urban women went to loan sharks (town shahukars) for funds. Only urban women who belonged to agricultural families and had relocated to cities/towns approached arthiyas. These findings show that there is a relationship between women's location and the type of informal financing they use. Those women entrepreneurs who belong to less privileged families had to approach landlords, ghumihars or village shahukars for money.

\subsection{Socio-cultural Progress: Factors explaining the increasing involvement of women in business}

Table x.1 indicates that many women were engaged in the service industry. Approximately 60 percent were running boutiques (semi-urban and urban areas), beauty parlours (semi-urban (towns) and urban areas), grocery shops (rural women) and five percent were in the travel 
industry or ran internet cafés (urban areas). They were operating at the local level, mostly alone but sometimes with one or two employees. Women who ran grocery shops in the rural areas did multiple tasks, such as sewing clothes, and beauty jobs. Most respondents were aged between 35-45 years old, and the majority of the businesses (65 per cent) were two years old and 24 percent were five years old. These women in the Indian Punjab have been establishing firms to earn their livelihood and raise families.

Sixty percent reported that they established a business as their husbands or other male relatives had an addiction to alcohol or drugs. Many women were apprehensive about the spread of these addictions in their society and were worried about future generations. They were concerned that even the government authorities are not taking productive steps to help the community. In our sample, only 40 percent of women had entrepreneurship-related training. Indeed, 25 percent of these respondents trained themselves (e.g. as a beautician or fashion designer) before marriage when their families were matchmaking for them. One of the respondents mentioned in the interview:

"I am happy that I did fashion design at that time but never thought that this will help me to earn my livelihood in the near future. "(WE26)

Of our respondents, 27 percent belong to the traditionally owner-cultivator dominated Jat caste. They prefer their daughters/daughters-in-law to be doctors, engineers or teachers rather than beauticians or fashion designers in boutiques. These occupations are considered to be 'low profile'; if their daughter or daughter-in-law takes up one of these occupations, the status or reputation of the family may be degraded. One of the most interesting results from this study was the significant influence caste had on the type of occupation and profession chosen by the entrepreneurs, especially women. This finding suggests fruitful avenues for future research. 


\section{Discussion}

Our study suggests that women can move away from their dominant traditional role in society and transcend traditional values by overcoming the challenges of securing formal financing for their firms. We explore these factors in more depth below and show how they occur within these coordinating mechanisms (Figure x.1). It is these factors that influence productive entrepreneurship and conversely it is the interaction between these influencing factors that can severely impact women's productive entrepreneurship. For example, a woman can have traditional 'roles', belong to a low caste, have strong family support, be poorly educated, but still go into business with the help of informal funding. This is in direct contrast to Western centric thinking, which suggests that women who possess these characteristics could not possibly start entrepreneurial businesses. We discuss societal progress and the interactions that occur between culture and society in more depth below, and specifically the impact on their firms. Women continue to face underlying problems and constraints in such emergent entrepreneurial ecosystems.

From a theoretical perspective, our chapter contributes to the development of the literature on emergent entrepreneurial ecosystems by proposing that an emergent entrepreneurial ecosystem must be contextualized and grounded in the unique social, cultural, familial, and economic context in which it is growing. It is not anticipated that emergent ecosystems will have all the elements of a fully developed entrepreneurial ecosystem but some elements are evident. The constraints and problems faced by women entrepreneurs in the Punjab's emergent entrepreneurial ecosystem are of different dimensions and magnitude, for social and cultural reasons. The gender discrimination that often prevails at all levels in many societies affects women in industry also, and the cumulative effect of psychological, social, economic, and educational factors act as impediments to women entrepreneurs entering mainstream business activities. 
For example, in this study, half of women reported gaining greater household autonomy as they supplement household incomes and their husbands respect them more. However, two fifths of them said that their autonomy within the family had decreased because loans have been invested in an unprofitable business and repayments cause difficulties. Often husbands blame them for these difficulties:

"It's you who decided to start the business and borrow money, now you have to return [it]. I cannot help you to repay that." (WE6, WE12, WE12-27, WE43)

Although most respondents borrowed with the consent of husbands and other male family members, one third reported that they acquired loans themselves. Thus accessing credit, particularly for starting an enterprise, is one of the major constraints they faced. Women in India often have fewer opportunities to gain access to credit than men. The reasons are various and include lack of collateral, and the negative perceptions that loan officers have towards women entrepreneurs as they (the loan officers) are unwilling to accept household assets as collateral.

\section{Conclusions}

In this chapter, we set out to explore the position of women entrepreneurs in an emergent entrepreneurial ecosystem. By drawing on the literature from other emerging economies and by empirically and theoretically contextualizing our study (Welter, 2011; Zahra, 2007; Zahra et al., 2014), we offer novel insights on how these entrepreneurs access and utilize entrepreneurial finance to support their firms. These insights are embedded in the cultural milieu, social structures and are influenced by their family role.

While there is little evidence in our exploratory study of higher-level policy support for these women, we have identified an emergent entrepreneurial ecosystem at the local level in the Punjab. Our empirical results show the interplay and interweaving that occurs between 
markets, human capital, finance, and education/training ${ }^{5}$. In the context of women entrepreneurs in the Punjab, we expand on Stam's (2015) definition of entrepreneurial ecosystems. Our research shows that there are a clear set of actors (women, customers, banks, moneylenders, even other family members such as husbands with addictions and others who expect money for weddings) in the ecosystem. However, the central characters are entrepreneurial women. We now develop three propositions suggesting further areas for research.

Women entrepreneurs in emergent entrepreneurial ecosystems possess few overall assets, suffer from weak enforcement of financial rights and the existence of unequal inheritance rights. Consequently, they have limited access to community and social resources. Gender-based obstacles, conventional thinking and socio-cultural values aggravate difficulties faced by women. Due to their lack of access to formal finance, women must approach informal lenders. A quarter of women interviewed reported incidents of sexual harassment by informal lenders, especially in the rural and semi urban areas. Indeed, one fifth who were exploited by informal lenders belonged to the scheduled classes or lower castes (Dalits: literally 'the oppressed'), or so-called 'untouchables', illustrating the relationship between their caste and types of treatment and behaviour by these informal lenders. Indeed, given the emergence of upward mobility of the dalits in India, future research must study whether the caste continues to play a role in the relationship and behavioural patterns (Chowduhry, 2009), to explain the levels of harassment reported by lower caste women. We suggest:

\footnotetext{
${ }^{5}$ Policy is the fifth core component of an entrepreneurial ecosystem identified by Manolova et al. (2016). As we have stated above, there is little evidence of policy interventions in the context of the Punjab and with regard to the women entrepreneurs who participated in our study.
} 
P1: An increase in the upward mobility of women will improve the treatment of those women from lower castes in seeking funds for entrepreneurial ventures from informal financial sources.

On the other hand, due to their embeddedness in patrilineal societies (Rahman, 1999) all women have fewer business contacts, less knowledge of how to deal with government bureaucracy and less bargaining power, which further limit their businesses. Since most women entrepreneurs operate on a small scale, they often find it difficult to access information. Most existing networks are male-dominated and they are sometimes not particularly welcoming to women and prefer to remain exclusive. Fifty percent of women entrepreneurs reported that - due to the fear of physical abuse or if their personal safety at stake - they are reluctant to approach these informal lenders. They were concerned that there was a lack of women informal lenders in the market, since the informal financing business is largely male dominated.

Thus the high financial (in terms of interest) and emotional cost is a major hindrance for developing new business contacts and relationships in a new business and obstacles for businesses owned by women. Moreover, their ability to tap into new markets requires expertise, knowledge and contacts. Women often lack access to training and experience on how to participate in the market place and are, therefore, unable to market their goods and services strategically. As kinship behaviour is enforced along caste lines in India (Karve, 1990); women from lower castes have no contacts, as people in high positions usually belong to the higher caste. We, therefore, suggest:

P2: An increase in the number of informal women lenders would improve the progress of entrepreneurial women in establishing business.

Additionally, our chapter unveils some unique contextually novel insights, including distinctive types of informal lenders (see also Sandhu et al., 2015) - including arthyias, 
ghumihar (potters), kirana store owners (village grocers), shahukars (village goldsmith) and zamindar (landlords). There is, however, a paradox in the sense that women in our study were capable of finding funds to finance productive entrepreneurship in their emergent entrepreneurial ecosystem. However, they were constrained by a number of negative actors and factors within their cultural milieu, their social structural ties and the expectations of their roles in the family. We believe:

P3: The wider the policy implementation and dissemination of information on the capability/financial paradox the greater the potential for women entrepreneurs to succeed in business.

Policy programmes and interventions targeting women entrepreneurs can succeed only if they take note of this paradox, as well as of the familial and social conditioning that reduces the confidence, independence and mobility of women. Women beneficiaries must themselves be encouraged to claim greater decision-making authority in family businesses, whether run in their names or not. This transition can only happen if women gain more confidence, knowledge and experience in dealing with the external world. They should also collaborate with other successful women entrepreneurs. Women entrepreneurs suffer from multiple burdens due to their homemaking, child rearing (and sometimes farming) responsibilities, but their contribution to the household economy in India, including the Punjab, is not well documented and goes mostly unrecognized in the national accounts. The changing role of women and their contribution to emergent entrepreneurial ecosystems that was explored in this study has been rarely discussed and, therefore, requires further investigation. 


\section{References}

Ács, Z.J. and Amorós, J.E. (2008), 'Entrepreneurship and competitiveness dynamics in Latin America', Small Business Economics, 31 (3), 305-322.

Ács, Z.J., Bardasi, E., Estrin, S. and Svejnar, J. (2011), 'Introduction to special issue of Small Business Economics on female entrepreneurship in developed and developing economies', Small Business Economics, 37 (4), 393-396.

Ács, Z.J., Autio, E. and Szerb, L. (2014), 'National Systems of Entrepreneurship: Measurement issues and policy implications', Research Policy, 43 (3), 476-494.

Ács, Z.J., Desai, S. and Klapper, L.F. (2008), 'What does “entrepreneurship” data really show?' Small Business Economics, 31 (3), 265-281.

Akoorie, M.E. (2011), 'A challenge to Marshallian orthodoxy on industrial clustering', Journal of Management History, 17 (4), 451-470.

Allison, T.H., McKenny, A.F. and Short, J.C. (2013), 'The effect of entrepreneurial rhetoric on micro lending investment: An examination of the warm-glow effect', Journal of Business Venturing, 28 (6), 690-707.

Amine, L.S. and Staub, K.M. (2009), 'Women entrepreneurs in sub-Saharan Africa: An institutional theory analysis from a social marketing point of view', Entrepreneurship \& Regional Development, 21 (2), 183-211.

Amorós, J.E. and Bosma, N. (2014), Global Entrepreneurship Monitor 2013 Global Report: Fifteen Years of Assessing Entrepreneurship Across the Globe, London, Global Entrepreneurship Research Association. 
Aterido, R. and Hallward-Driemeier, M. (2011), 'Whose business is it anyway?'. Small Business Economics, 37 (4), 443-464.

Bardasi, E., Sabarwal, S. and Terrell, K. (2011), 'How do female entrepreneurs perform? Evidence from three developing regions', Small Business Economics, 37 (4), 417-441.

Bhagavatula, S., Elfring, T., van Tilburg, A. and van de Bunt, G.G. (2010), 'How social and human capital influence opportunity recognition and resource mobilization in India's handloom industry', Journal of Business Venturing, 25 (3), 245-260.

Birtchnell, T. (2011), 'Jugaad as systemic risk and disruptive innovation in India', Contemporary South Asia, 19 (4), 357-372.

Bruhn, M. and Love, I. (2011), 'Gender differences in the impact of banking services: evidence from Mexico', Small Business Economics, 37 (4), 493-512.

Brush, C.G. and Cooper, S.Y. (2012), 'Special Issue: Female entrepreneurship and economic development: an international perspective', Entrepreneurship \& Regional Development, 24 $(1-2), 1-6$.

Campbell, N.D. and Rogers, T.M. (2012), 'Microfinance institutions: A profitable investment alternative?' Journal of Developmental Entrepreneurship, 17 (4), 1-11.

Cetindamar, D., Gupta, V.K., Karadeniz, E. and Egrican, N. (2012), 'What the numbers tell: The impact of human, family and financial capital on women and men's entry into entrepreneurship in Turkey', Entrepreneurship \& Regional Development, 24 (1/2), 29-51.

Chowdhury, F. and Audretsch, D.B. (2014), 'Institution as looting apparatus: impact of gender equality and institutions on female entrepreneurship', Eurasian Business Review, 4 (2), 207-225. 
Chowdhury, P. (2009), 'First our jobs then our girls: the dominant caste perceptions on the rising Dalits', Modern Asian Studies, 43 (2), 437-479

Coad, A. and Tamvada, J. (2012), 'Firm growth and barriers to growth among small firms in India', Small Business Economics, 39 (2), 383-400.

De Gobbi, M.S. (2003), 'Mutual guarantee associations for small and micro entrepreneurs: Lessons learned from Europe and Africa', African Development Review, 15 (1), 23-34.

de Mel, S., McKenzie, D. and Woodruff, C. (2008), 'Returns to capital in microenterprises: Evidence from a field experiment', Quarterly Journal of Economics, 123 (4), 1329-1372.

de Mel, S., McKenzie, D. and Woodruff, C. (2014), 'Business training and female enterprise start-up, growth, and dynamics: Experimental evidence from Sri Lanka', Journal of Development Economics, 106 (1), 199-210.

Dechant, K. and Al Lamky, A. (2005), 'Toward an understanding of Arab women entrepreneurs in Bahrain and Oman', Journal of Developmental Entrepreneurship, 10 (2), 123-140.

Della-Giusta, M. and Phillips, C. (2006), 'Women entrepreneurs in the Gambia: Challenges and opportunities', Journal of International Development, 18 (8), 1051-1064.

Desai, S. (2009), 'Measuring entrepreneurship in developing countries', United Nations University (UNU)-World Institute for Development Economics Research (WIDER) research paper 2009/10, Helsinki, UNU-WIDER.

Elam, A. and Terjesen, S. (2010), 'Gendered institutions and cross-national patterns of business creation for men and women', European Journal of Development Research, 22 (3), $331-348$. 
Government of India (2016) http://punjab.gov.in/know-punjab (Accessed 19 April 2016).

Gurtoo, A. (2009), 'Policy support for informal sector entrepreneurship: Micro-enterprises in India', Journal of Developmental Entrepreneurship, 14 (2), 181-194.

Habib, S.M.A. and Shah, P. (2010), 'Economics of integrating access to finance and access to information in Bangladesh economy', Banking \& Finance Letters, 2 (1), 241-248.

Hartwell, C.A. (2014), 'Capital controls and the determinants of entrepreneurship', Finance a Uver, 64 (6), 434-456.

Henn, S. (2013), 'Transnational entrepreneurs and the emergence of clusters in peripheral regions. The case of the diamond cutting cluster in Gujarat (India)', European Planning Studies, 21 (11), 1779-1795.

Holmén, M., Min, T.T. and Saarelainen, E. (2011), 'Female entrepreneurship in Afghanistan', Journal of Developmental Entrepreneurship, 16 (3), 307-331.

Hussain, J.G. and Scott, J.M. (Eds.) (2015), Research Handbook on Entrepreneurial Finance, Cheltenham, Edward Elgar.

Iftekhar, H., Ayub, A., Razzaq, A. and Aslam, M.S. (2013), 'Problems in entrepreneurial capital generation and importance of governmental reforms to resolve; in underdeveloped countries’, Business Management Dynamics, 2 (10), 70-73.

International Finance Corporation (2014), 'Women-owned Businesses in India' [Online]. Available from http://www.ifc.org/wps/wcm/connect/a17915804336f2c29b1dff384c61d9f7/Womenownedbu siness1.pdf?MOD=AJPERES (Accessed on 12 $2^{\text {th }}$ June 2015). 
Irwin, D., Pattinson, S. and Scott, J.M. (2014), 'Local enterprise agency loan funds and investment readiness in UK small firms', Local Economy, 29 (1-2), 7-19.

Karve, I. (1990), Kinship Organization in India, third edition, New Delhi, Munshiram Manolal Publishers.

Kelley, D.E., Brush, C.G., Greene, P.G and Litovsky, Y. (2013), Global Entrepreneurship Monitor 2012 Women's Report, London, Global Entrepreneurship Research Association.

Kent, D. and Dacin, M.T. (2013), 'Bankers at the gate: Microfinance and the high cost of borrowed logics', Journal of Business Venturing, 28 (6), 759-773.

Keshabananda, D. (1998), 'Collective dynamism and firm strategy: study of an Indian industrial cluster', Entrepreneurship \& Regional Development, 10 (1), 33-49.

Khavul, S., (2010) ‘Microfinance: Creating Opportunities for the poor?' Academy of Management Perspectives, 24 (3), 58-72.

Kobeissi, N. (2010), 'Gender factors and female entrepreneurship: International evidence and policy implications', Journal of International Entrepreneurship, 8 (1), 1-35.

Koster, S. and Kumar Rai, S. (2008), 'Entrepreneurship and economic development in a developing country: A case study of India', Journal of Entrepreneurship, 17 (2), 117-137.

Latha, K.L. and Murthy, B.E.V.V.N. (2009), 'The motives of small scale entrepreneurs: An exploratory study', South Asian Journal of Management, 16 (2), 91-108.

Loh, J.M.I. and Dahesihsari, R. (2013), 'Resilience and economic empowerment: a qualitative investigation of entrepreneurial Indonesian women', Journal of Enterprising Culture, 21 (1), 107-121. 
Makarfi, A. M. and Olukosi, J. O. (2011), 'Microfinance institutions as vehicles for sustainable credit access by the poor in Kano state, Nigeria', European Journal of Finance \& Banking Research, 4 (4), 34-48.

>introductory chapter to be updated when final version received: Manolova, T. ET AL. (2016) ‘ TITLE’, in T. Manolova, L. Edelman, A. Robb, F. Welter and C. Brush (Eds.), Entrepreneurial Ecosystems and Growth of Women's Entrepreneurship: A Comparative Analysis, Cheltenham, Edward Elgar, pp. 1-??.

Morduch, J. (1999), 'The microfinance promise', Journal of Economic Literature, 37 (4), 1569-2004.

MSME. (2015-2016), Ministry of Micro, Small and Medium Enterprises, Government of India, Annual report 2015-2016, [Online]. Available at: http://msme.gov.in/WriteReadData/KMS/MSME_at_a_GLANCE_Book_Final.pdf (Accessed on 19th April 2016].

Muravyev, A., Talavera, O. and Schäfer, D. (2009), 'Entrepreneurs' gender and financial constraints: Evidence from international data', Journal of Comparative Economics, 37 (2), 270-286.

Nafziger, E.W. and Terrell, D. (1996), 'Entrepreneurial human capital and the long-run survival of firms in India', World Development, 24 (4), 689-696.

Nichter, S. and Goldmark, L. (2009), 'Small firm growth in developing countries', World Development, 37 (9), 1453-1464.

Nziramasanga, M.T., Bhattacharjee, S. and Lee, M. (2009), 'Viability of self-employment', Journal of Development Studies, 45 (7), 1070-1092. 
Olarenwaju, O.A. and Olabisi, Y.S. (2012), 'Women's access to entrepreneurial resources in informal economy: A qualitative analysis of Yoruba women textile traders' access to entrepreneurial resources at Balogun Market, Lagos -- South-West, Nigeria’, Economic Insights - Trends \& Challenges, 64 (3), 30-43.

Parida, P. and Sinha, A. (2010), 'Performance and sustainability of self-help groups in India: A gender perspective', Asian Development Review, 27 (1), 80-83.

Peiris, I., Akoorie, M. and Sinha, P. (2015), 'Resourcing indigenous export ventures through networks: insights from the Sri Lankan tea industry'. In J.G. Hussain and J.M. Scott (Eds.), Research Handbook on Entrepreneurial Finance, Cheltenham, Edward Elgar, pp. 82-101.

Perri, D. F. and Chu, H. M. (2012), 'Entrepreneurs in China and Vietnam: Motivations and problems', International Journal of Entrepreneurship, 16 (1), 93-112.

Porter, M. (1990), The Competitive Advantages of Nations, New York: The Free Press.

Prasad, R.M. (2009), 'Loan hurdles: Do banks discriminate against women entrepreneurs?', Academy of Management Perspectives, 23 (4), 91-93.

Pretes, M. (2002), 'Microequity and microfinance', World Development, 30 (8), 1341-1353. Population of Punjab (2016), Punjab's Population 2016. [Online]. Available at http://www.indiaonlinepages.com/population/punjab-population.html (Accessed on 18th April 2016)

Rahman, A. (1999), 'Micro-credit initiatives for equitable and sustainable development: Who pays?' World Development, 27 (1), 67-82. 
Rai, U.K. and Srivastava, M. (2011), 'Aspirations and motives of women entrepreneurs: An empirical study of Varanasi district', IUP Journal of Entrepreneurship Development, 8 (2), 23-33.

Ramachandran, K. and Ramnarayan, S. (1993), 'Entrepreneurial orientation and networking: Some Indian evidence', Journal of Business Venturing, 8 (6), 513-524.

Romani, G., Atienza, M. and Amorós, J.E. (2009), 'Financing entrepreneurial activity in Chile: scale and scope of public support programs'. Venture Capital, 11 (1), 55-70.

Roper, S. (2013) Entrepreneurship: A Global Perspective. Routledge: London.

Sandhu, N., Hussain, J. and Matlay, H. (2012), 'Barriers to finance experienced by female owner/managers of marginal farms in India'. Journal of Small Business and Enterprise Development, 19 (4), 640-655.

Sandhu, N., Hussain, J.G. and Matlay, H. (2015), 'Informal lenders and small/marginal farmers in India: an unregulated sociological symbiotic relationship?' In J.G. Hussain and J.M. Scott (Eds.), Research Handbook on Entrepreneurial Finance, Cheltenham UK, Edward Elgar, pp. 206-228.

Shetty, N.K. (2009), 'The microfinance promise in financial inclusion: Evidence from India', IUP Journal of Applied Economics, 8 (5/6), 174-189.

Singer, S., Amorós, J.E. and Moska, D. (2015), Global Entrepreneurship Monitor 2014 report, London, Global Entrepreneurship Research Consortium.

Singh, A. (2010), 'Role of small-scale industries in district level development: A study of Varanasi', IUP Journal of Entrepreneurship Development, September, 6-22. 
Singh, S.P., Reynolds, R.G. and Muhammad, S. (2011), 'A gender-based performance analysis of micro and small enterprises in Java, Indonesia', Journal of Small Business Management, 39 (2), 174-182.

Smahi, A., Arif, S.E. and Maliki, S. (2012), 'Microfinance et pauvreté subjective en Algérie: essai d'analyse' [Microfinance and subjective poverty in Algeria : primary Analysis], Revue des Sciences de Gestion, 255-256, 133-141.

Stam, E. (2015), 'Entrepreneurial ecosystems and regional policy: A sympathetic critique', Utrecht School of Economics, Discussion Paper Series, 15-07, Utrecht, Netherlands, Utrecht School of Economics.

Tambunan, T. (2007), 'Development of SME and women entrepreneurs in a developing country: The Indonesian story', Small Enterprise Research, 15 (2), 31-51.

Tambunan, T. (2008), 'SME development, economic growth, and government intervention in a developing country: The Indonesian story', Journal of International Entrepreneurship, 6 (4), 147-167.

Torri, M.C. and Martinez, A. (2014), ‘Women's empowerment and micro-entrepreneurship in India: Constructing a new development paradigm? Progress in Development Studies, 14 (1), 31-48.

Vivarelli, M. (2013), 'Is entrepreneurship necessarily good? Microeconomic evidence from developed and developing countries', Industrial \& Corporate Change, 22 (6), 1453-1495.

Welter, F. (2011), 'Contextualizing entrepreneurship - conceptual challenges and ways forward', Entrepreneurship Theory and Practice, 35 (1), 165-184. 
Williams, D.A. and K'nIfe, K.A.K. (2012), 'Correlates of gender and credit behavior in small firms: Evidence from a small, developing economy', Entrepreneurial Executive, 17 (1): 6985.

Woller, G, M., and Woodworth, W. (2001), 'Microcredit as a grass-roots policy for international development', Policy Studies Journal, 29 (2), 267-282.

Wydick, W.B. (1999), ‘Credit access, human capital and class structure mobility’, The Journal of Development Studies, 35 (6), 131-152.

Wydick, B. (2002), 'Microfinance among the Maya: Tracking the progress of borrowers', Development \& Change, 33 (3), 489-509.

World Bank (2004), Resuming Punjab’s Prosperity: Opportunities and Challenges Ahead, New Delhi: Poverty Reduction and Economic Management Sector Unit South Asia Region.

World Bank. (2009), Agriculture for Development, Washington, DC: The World Bank, Available at http://siteresources.worldbank.org/INTWDR2008/Resources/WDR_00_book.pdf (Accessed 15 December 2015).

Zahra, S. (2007), 'Contextualizing theory building in entrepreneurship research', Journal of Business Venturing, 22 (3), 443-452.

Zahra, S., Wright, M., and Abdelgawad, S. (2014), 'Contextualization and the advancement of entrepreneurship research', International Small Business Journal, 32 (5), 479-500. 
Figure x.1:

Gender, Access to Finance and Societal Progress in an Emergent Entrepreneurial Ecosystem

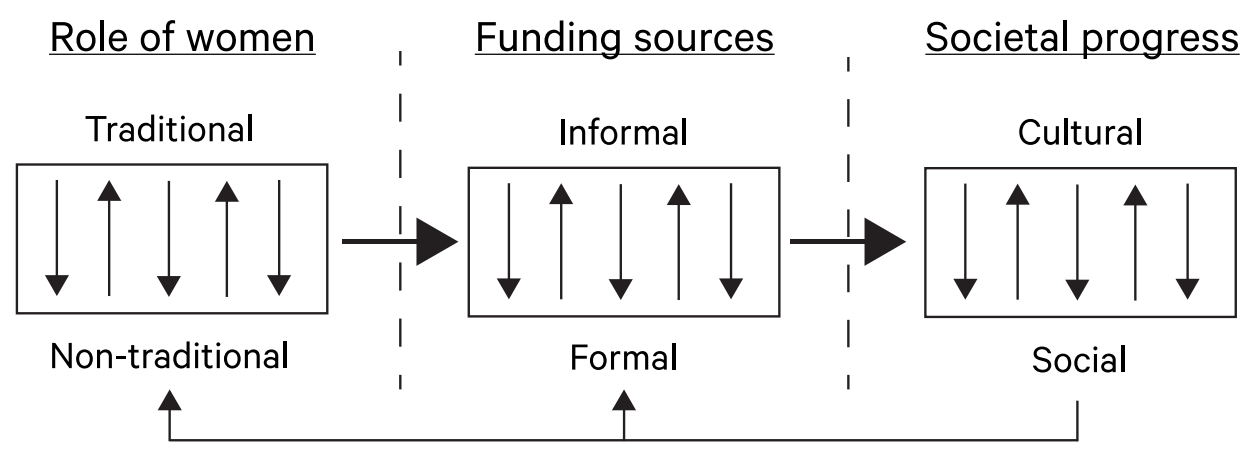

Explanation: The dominant coordinating mechanisms for (1) Role of Women are: Non-traditional, where arrows represent bi-directional forces e.g. traditional (child rearing), non-traditional (business owner); (2) Funding Sources mechanisms are: (In) Formal, with forces e.g. informal (family sources), formal (money lenders); (3) Societal Progress mechanisms: cultural/social, with forces; cultural (change in caste system values), social (improved policy implementation). 
Table x.1: Demographics of the Research Sample

\begin{tabular}{|c|c|c|}
\hline Demographic Variables & $\begin{array}{l}\text { Women Entrepreneurs } \\
\mathrm{N}=185\end{array}$ & $\begin{array}{l}\text { Percentage } \\
\%\end{array}$ \\
\hline \multicolumn{3}{|l|}{ Gender } \\
\hline Women & 185 & 100 \\
\hline \multicolumn{3}{|l|}{ Age of WEs (years) } \\
\hline $25-34$ & 46 & 25 \\
\hline $35-44$ & 74 & 40 \\
\hline $45-54$ & 54 & 29 \\
\hline 55 or older & 11 & 6 \\
\hline \multicolumn{3}{|l|}{ Caste } \\
\hline Jat & 50 & 27 \\
\hline Others & 135 & 73 \\
\hline \multicolumn{3}{|l|}{ Marital Status } \\
\hline Married & 157 & 85 \\
\hline Divorced & 2 & 1 \\
\hline Widowed & 22 & 12 \\
\hline Single & 4 & 2 \\
\hline \multicolumn{3}{|l|}{ Education } \\
\hline Below Matriculation & 10 & 5 \\
\hline Matriculation & 30 & 16 \\
\hline Graduate & 70 & 38 \\
\hline Postgraduate & 20 & 11 \\
\hline Technical Diploma Holders & 50 & 27 \\
\hline Uneducated & 5 & 3 \\
\hline \multicolumn{3}{|l|}{ Family Responsibilities } \\
\hline Main Earner & 140 & 76 \\
\hline \multicolumn{3}{|l|}{ Reason for business } \\
\hline Economic Necessity & 140 & 76 \\
\hline \multicolumn{3}{|l|}{ Entrepreneurship related training } \\
\hline Yes & 75 & 40 \\
\hline No & 110 & 60 \\
\hline \multicolumn{3}{|l|}{ Obtain Financial consultation from } \\
\hline Family and Friends & 120 & 65 \\
\hline Bank Manager & 37 & 20 \\
\hline Accountant & 18 & 10 \\
\hline Lawyer & 0 & 0 \\
\hline Government and Support Agencies & 10 & 5 \\
\hline \multicolumn{3}{|l|}{ Age of the Business (Years) } \\
\hline$<2$ & 105 & 57 \\
\hline $2-4$ & 44 & 24 \\
\hline $5-7$ & 25 & 13 \\
\hline $8-10$ & 7 & 4 \\
\hline$>10$ & 4 & 2 \\
\hline \multicolumn{3}{|l|}{ Size of business* } \\
\hline Micro & 120 & 65 \\
\hline Small & 55 & 30 \\
\hline Medium & 10 & 5 \\
\hline \multicolumn{3}{|l|}{ Sector } \\
\hline Service & 120 & 65 \\
\hline Farm related business activities & 37 & 20 \\
\hline Manufacturing & 25 & 13 \\
\hline IT based business & 3 & 2 \\
\hline
\end{tabular}

*Categorized according to Small Scale Industry definition based on the investment 
Table x.2: Bank finance used (by business age in years)

\begin{tabular}{lllllll}
\hline $\begin{array}{l}\text { Loan } \\
\text { rejection }\end{array}$ & $<\mathbf{2}$ & $\mathbf{2 - 4}$ & $\mathbf{5 - 7}$ & $\mathbf{8 - 1 0}$ & $\mathbf{> 1 0}$ & Total \\
Yes & 7 & 15 & 22 & 7 & 3 & 54 \\
No & 98 & 29 & 3 & 0 & 1 & 131 \\
Total & 105 & 44 & 25 & 7 & 4 & 185 \\
\hline
\end{tabular}

(Chi-square $=16.273, d f=3, p=.003)$

Table x.3: Borrowing from various informal sources

\begin{tabular}{|c|c|c|c|c|c|c|}
\hline \multirow[b]{2}{*}{$\begin{array}{l}\text { Types of } \\
\text { Informal } \\
\text { Providers }\end{array}$} & \multicolumn{4}{|c|}{ Age of business (in years) } & \multirow[b]{2}{*}{$>10$} & \multirow[b]{2}{*}{$\begin{array}{l}\text { Total } \\
\mathrm{N}=131\end{array}$} \\
\hline & $<2$ & $2-4$ & $5-7$ & $8-10$ & & \\
\hline Arthiyas & 20 & 10 & Nil & Nil & Nil & 30 \\
\hline Landlords & 10 & 5 & Nil & Nil & Nil & 15 \\
\hline $\begin{array}{l}\text { Village/town } \\
\text { Sahukars }\end{array}$ & 20 & 15 & 5 & Nil & Nil & 40 \\
\hline Ghumihar & 2 & Nil & Nil & Nil & Nil & 2 \\
\hline $\begin{array}{l}\text { Village/ town } \\
\text { grocer }\end{array}$ & 3 & 2 & Nil & Nil & Nil & 5 \\
\hline Friends/family & 22 & 10 & 5 & 2 & Nil & 39 \\
\hline
\end{tabular}

